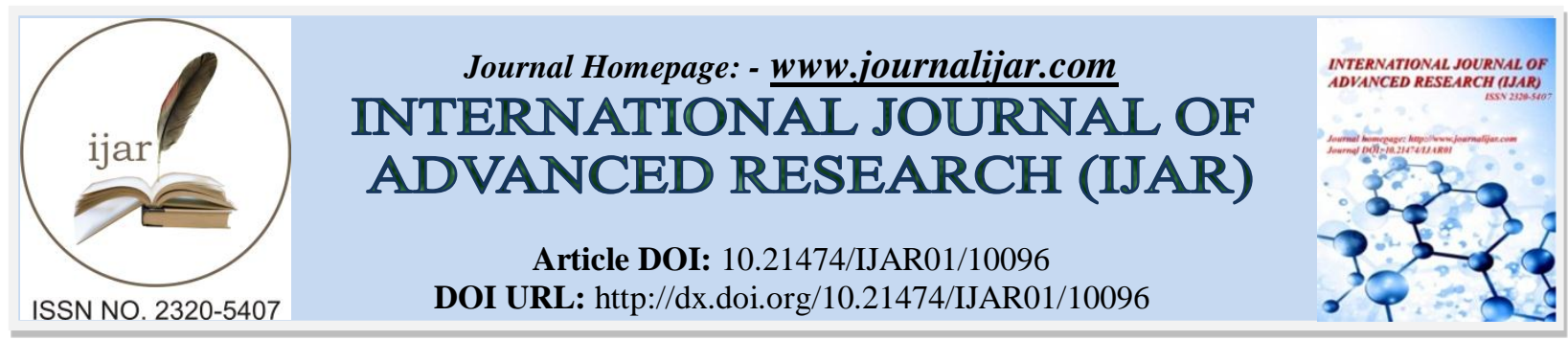

RESEARCH ARTICLE

\title{
AGE DOES NOT AFFECT THE ACCEPTANCE AND USE OF MOBILE PAYMENT IN INDONESIA.
}

\author{
Kania Kismadi, Rini Inthalasari and Minsani Mariani. \\ Binus Business School, Jakarta.
}

\section{Manuscript Info}

\section{Manuscript History}

Received: 14 September 2019

Final Accepted: 16 October 2019

Published: November 2019

\section{Key words:-}

fintech, mobile payment, UTAUT2, acceptance and usage factor, customer segment, Indonesia.

\begin{abstract}
This study aims to determine factors can influence the level of acceptance and use of mobile payments based on different groups of people because consumers with different age segments have different desires and abilities in terms of needs and acceptance of new technology. The used research method was a survey through questionnaires which have been distributed to 400 samples from the population of mobile payment users in Indonesia, aged of 18 to 55 years old, and they were analyzed by using SEM-PLS Analysis Techniques. The results of the study showed that the human population did not affect the intended or actual use of mobile payments. Variables that have a significant influence on the acceptance and use of mobile payments in Indonesia are Performance Expectancy, Facilitating Condition, Hedonic Motivation, and Habit. However, there was no significant difference in the strong effect of variables between the old and young age groups.
\end{abstract}

Copy Right, IJAR, 2019,. All rights reserved.

\section{Introduction:-}

The FinTech industry in Indonesia has grown rapidly in the last two years. As in 2018 there were more than 150 registered FinTechs, or an increase of 78\% from 2015. Interestingly, 44\% of existing FinTechs were included in the category of mobile payments (Cekindo, 2018), with a total value of transactions reaching up to USD 22,427 millions in 2018, and it will have been predictably increasing to $13.5 \%$ in 2020 ( Statista, 2018). FinTech (Financial Technology) itself is defined as a new financial industry that uses technology to increase its financial activity (Schueffel, 2016). Furthermore, FinTech is also defined as a company that develops various information technologybased financial products and services (Varga, 2017).

With a total population of 265.4 millions, The Fin Tech internet penetration has reached $50 \%$ or 132.7 million users, meanwhile its mobile penetration has gone up to $67 \%$ or 177.9 million users (We Are Social, 2018). Also, in the mobile payment category it is predicted to continously developing. FinTech's market potential is still very promising, because $69 \%$ of mobile phone users have not been touched by fintech (CNN Indonesia, 2018).

As mobile payment is developing more and more, researches on it, are being done. More than 1.9 million journal studies have been found regarding with the mobile payment on Google Scholar. Specifically, there are more than 50,000 research journals about mobile payment in Indonesia, which can be found on Google Scholar. Consumer factors are the most popular research areas among researchers (Dennehy \& Sammon, 2015). Evidently, there have been also over 20,000 studies concerning with the acceptance, usage, or adoption factors for mobile payment on Google Scholar. 
From previous studies about adopting mobile payment factors, there is research states that young generation is more capable of accepting new technologies, while older generation will need more assistance in implementing their services (Cabanillas, Fernández, \& Leiva, 2015). This is in line with the statement of the FinTech Indonesia Association (AFTECH) says that, more segments of the market need to be implemented (Cabanillas, Fernández, \& Leiva, 2015). In Indonesia is a millennial with 25-35 years old (AFTECH, 2018). The EY FinTech Adoption Index 2017 also indicates that groups of people who use FinTech tend to target consumers around 25-34 years old. Here,we can see that the tendency of mobile payment is more acceptable to the certain segments (younger generation) rather than others (older generation). However, there is also a research states that people do not have a significant relationship to e-payment adoption in Indonesia (Riskinanto, Kelana, \& Hilmawan, 2017).

From some of the studies above, it can be seen that there are still differences in the effect of age related to the factor of acceptance and using mobile payment. Some say that age has an effect, some don't. It is important to know that mobile payment service companies understand the needs of each group of users. Because it is only by knowing the characters and the needs of each different group of people, the company can increase the level of its users for its mobile applications, as it only ends up in the end.For this reason, this research wants to find out whether there is an influence of the acceptance and use of mobile payment in Indonesia, as well as the strength of the relationships factors between the influence of the acceptance and use of mobile payment and, in the different segments of humans.

\section{Literature Review Mobile Payment}

Karnouskos and Focus defines the mobile payment as a payment where cellular devices are used to start, activate, and / or confirming any it (Daştan \& Gürler, 2016). Gartner also defines that mobile payment as a transaction does through cellulars and the payment instruments included are banking instruments such as repayments, bank accounts, credit / debit cards, Stored Value Accounts (SVAs), for Paypal or mobile wallet.

The increase in mobile payment services through out the world are also increasing the amount of researches on mobile payment itself, especially in the terms of technology acceptance and use from the perspective of consumers. Various acceptance and use of technology is used in it, beginning with Innovation Diffusion Theory (TAM) and Theory of Planned Behavior by Davies in Davies in 1962, Theory of Reasoned Action (TRA) by Fishbein and Ajzen in 1975, Technology Adoption Model (TAM) and Theory of Planned Behavior by Davies in 1986 and 1992, Motivational Model (MM) by Davis et.al. in 1992, to the Unified Theory of Acceptance Use of Technology (UTAUT) and UTAUT2 by Venkatesh et.al. in 2003 and 2012 (Dennehy \& Sammon, 2015).

\section{Unified Theory of Acceptance and Use of Technology 2}

The Unified Theory of Acceptance Use of Technology was first introduced by Viswanath Venkatesh, Michael G. Morris, Gordon B. Davis, and Fred D. Davis in 2003 who brought together eight others theories of the technology acceptance. The theory has four main determinants that influence user acceptance and usage behavior, namely Performance Expectancy (PE), Effort Expectancy (EE), Social Influence (SI), and Facilitating Conditions (FC). In addition, UTAUT theory also states that there are four factors of moderation that have influenced user acceptance and usage behavior, ie, Facilitating Conditions (FC). gender, age, experience, and voluntariness of use.

Afterwards in 2012, Venkatesh et.al. developed the theory into UTAUT2 which is more focused on the context of consumer use (consumer use context). In this extended version, Venkatesh et.al. has added three main determinants, namely Hedonic Motivation (HM), Price Value (PV), and Habit (HB). While voluntariness of use was eliminated from normative moderation, just leaving age, gender, and experience as modern norms in the acceptance and use of new technology.

This research uses the modified UTAUT2 theory model with the focus of this research. There are seven independent variables that we have examined, namely $\mathrm{PE}, \mathrm{EE}, \mathrm{SI}, \mathrm{FC}, \mathrm{HM}, \mathrm{PV}$, and $\mathrm{HB}$, and two dependent variables, namely Behavioral Intention (BI) and Use Behavior (UB). In addition, the independent variable is moderated by human variable. Modifications which are applied is to include in eliminating the variables of experience and gender moderations that affect the independent variable on the dependent variable, because this research wants to focus on how we influence the behavioral intention and behavioral use of mobile payments in Indonesia. 


\section{Age as a moderating factor}

Kotler and Keller stated that the desires and abilities of consumers changed with the changing people (2016). Consumer behavior is also influenced by three factors, namely cultural, social, and personal factors. One of the personal factors is human. Research on the factors of influencing the behavior of these consumers can also provide information on how to reach out and serve consumers more effectively (Kotler \& Keller, 2016).

Age was chosen to be a moderating variable because different age groups have different behaviors. So, when age is used as a moderating variable, each variable will have different effect strength on the acceptance and use of mobile payment.

There is research which suggests that more consumers have a tendency to be more difficult in the promotion of new technology, so as to influence the learning process of their new technology (Morris et al. 2005; Plude and Hoyer 1985, as included in Venkatesh, 2012). There is also research that shows that the younger generation is more able to accept new technology, while the older generation will need more assistance in implementing its services (Cabanillas, Fernández, \& Leiva, 2015).

However, there is a research that also states that it is not the fact of moderation that also influences PE, EE, SI, FC, HM, PV, and HB towards the intention of using internet marketing in Malaysia and Taiwan (Isa \& Wong, 2015). Other research also states that we do not have a significant relationship to e-payment adoption in Indonesia, except for the Perceived Ease of Use and Perceived Usefulness factors, with relatively small relationships (Riskinanto, Kelana, \& Hilmawan, 2017).

From some of the studies above, it can be seen that there are still differences in the effect of age on the factor of acceptance and use of mobile payment. Some say that age has an effect, some don't. In addition, studies have not yet been found in detail in detail about how weak are the relationships between the factors that have influenced the acceptance and use of mobile payments, in different segments of people. It is important to know that mobile payment service providers understand the needs of each group of users. By understanding the character and behavior of the generators, it will be easier for businesses to embrace and build good relationships with their consumers, so that the needs of all consumers can be fulfilled, which would result in the increased adoption of mobile payment, and leading it to the improvement of the performance in the company.

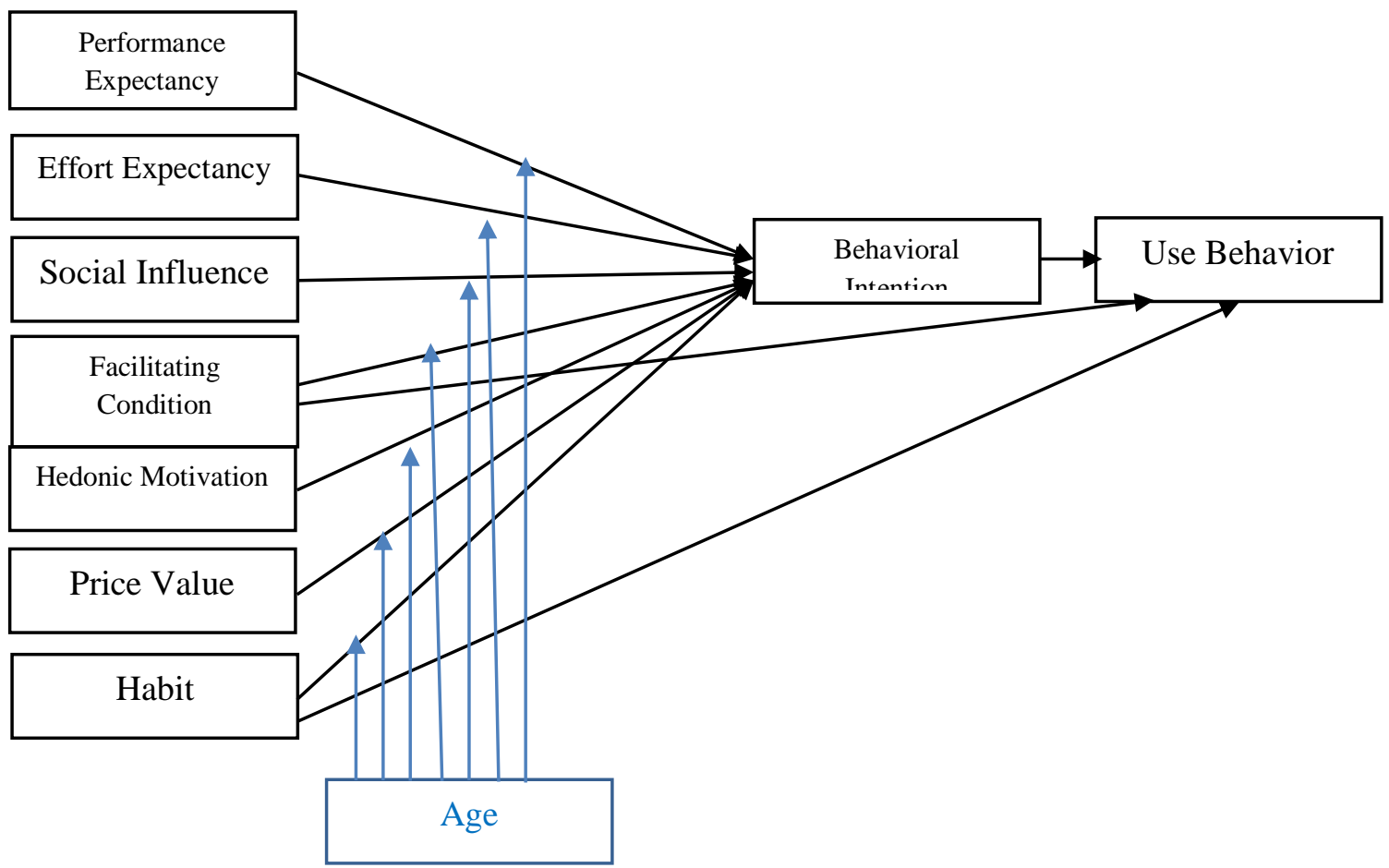




\section{Performance Expectancy}

Performance Expectancy (PE) is defined as the level at which a person believes that by using the system or technology, he will get the benefits of his activities, in terms of mobile payment activities. When PE is fulfilled positively and significantly, then the greater intention would get people to use certain technologies, in this case mobile payment.

Several previous studies have also proven that Performance Expectancy is the strongest factor in determining the intention and use of technology (Schaupp, et al., 2010; Kijsanayotin, Pannarunothai, \& Speedie, 2009; Zhou et al., 2010, quoted in Chang, 2012). Hall and Mansfield, 1975 also stated that age plays a moderating role in the relationship between Performance Expectancy and Behavior Intention in technology acceptance, where younger people are more concerned with extrinsic rewards (Isa \& Wong, 2015)

\section{H1: Effect of Performance Expectancy on Behavioral Intention is stronger in younger age groups}

\section{Effort Expectancy}

Effort Expectancy (EE) is defined as the level of ease of using of a system or the technology system, for people to use mobile payment.

There are several different research resulted in assessing the Perceived Ease of Use or Perceived Usefulness that can be included in the category of Effort Expectancy. There is a result that states that the Perceived Ease of Usage and Usefulness do not have a significant specification of the use of mobile payment (Daştan \& Gürler, 2016). There are also results which state that both of these factors have a significant impact on the use of mobile payments (Schierz et al., 2010; Kim et al., 2010, as written in Daştan \& Gürler, 2016).

Another one that makes the difference is that mobility, or the factors that allow the use of transactions wherever possible with ease (effort expectancy), also have contradictory on the research results. Kim, Park, Choi, \& Yeon, 2016 stated that mobility does not affect the intention to use mobile payment. While Daştan \& Gürler's research, 2016 states that perceived mobility has a positive effect on the adoption of mobile payments.

In addition, age is also a moderator in the relationship between Effort Expectancy and Behavioral Intention, where people with older age will find it more difficult to process more complex stimuli (Plude \& Hoyer, 1985, as quoted in Isa \& Wong, 2015).

\section{H2: Effect of Effort Expectancy on Behavioral Intention is stronger in the older age group}

\section{Social Influence}

Social Influence (SI) is defined as the level at which people around users use the same system or technology, so the users feel that they have to use it as well.

Kim, Park, Choi, \& Yeon, 2016 states that social influence has a positive relationship with the intention to use, meaning that, social influence can affect the acceptance and use of mobile payment. With the increasing use of social media, consumers are more likely to transfer knowledge. However, this may not be obtained by older consumers, because they are less active in social media, so social influence and affiliation are more needed in order to receive new technology (Isa \& Wong, 2015).

\section{H3: The effect of Social Influence on Behavioral Intention is stronger in the older age group}

\section{Facilitating Conditions}

Facilitating Conditions (FC) are defined as supporting infrastructure that increases user intentions to use mobile payments, such as networks, the number of merchants that exist, and the completeness of other machines that support the payment.

The results of Dahlberg et.al's research in 2006 stated that merchants also had an important role in implementing mobile payments. The more merchants, the easier will be to find them, the more people who use mobile payment services, the viral effect in the social environment (Manaf \& Ariyanti, 2017). Age also plays a role of moderation, where older people are more in need of Facilitating Conditions than those who are younger (Isa \& Wong, 2015). 
H4a: Effect of Facilitating Condition on Behavioral Intention is stronger in the older age group H4b: The effect of facilitating conditions on us behavior is stronger in the older age group

\section{Hedonic Motivation}

Hedonic Motivation (HM) is defined as the pleasure obtained from using a specific technology. Hedonic Motivation is also found as an important determinant of technology in the acceptance and use of technology (Brown \& Venkatesh, 2005, in Isa \& Wong, 2015).

A study also states that Hedonic Motivation is very strong in influencing the intention to use ABC easy tap (Manaf \& Ariyanti, 2017), where the results of this study also support the UTAUT 2 theory that Hedonic Motivation is one of the very strong determinants in consumer products and that Hedonic Motivation has a strong influence on Behavioral Intention in a group of younger men (Venkatesh, Thong, \& Xu, 2012).

\section{H5: The effect of Hedonic Motivation on behavioral intention is stronger in younger age groups}

\section{Price Value}

Price Value (PV) is defined as the value or value between the benefits obtained and the costs that must be spent to use a particular system or technology. PV is positive when the benefits gained are greater than the costs incurred, and this supports the positive impact on the intended use. When using the sense of value, the value obtained is greater than the costs incurred (PV is positive and significant), so the use of certain positive technologies (mobile payment) increases.

The importance of Price Value among young consumers and consumers has also been theorized by Deaux \& Lewis in 1984, where young consumers are believed to be too sensitive to the prices of older consumers (Isa \& Wong, 2015).

\section{H6: The influence of Price Value on behavioral intention is stronger in the older age groups}

\section{Habit}

Habit (HB) is defined as the extent to which users use technology automatically based on learning in the past. HB is also indicated as one of the biggest factors that is able to explain the use of technology (quoted from Limayem et al. 2007 in Ventakesh et.al 2012: 161). Significant and positive HB values also have a direct impact on use and behavior, because it has become a habit.

Manaf \& Ariyanti, 2017, stated that from 8 factors, only 6 had positive and significant effects on intention to use, namely Habit, Price Value, Trust, Hedonic Motivation, Facilitating Condition, and Performance Expectancy. While Effort Expectancy and Social Influence have positive effects, but they are not significant. While usage behavior is influenced by Habit, Facilitating Condition, and Trust.

Isa \& Wong (2015) also wrote about the results of Lustig, Konkel, and Jacoby research in 2004, where older people have a habit that prevents them from learning new things, where older people tend to rely on automatic information processing.

H7a: Habit's influence on behavioral intention is stronger in the older age groups H7b: Habit's influence on use behavior is stronger in older age groups

\section{Behavioral Intention}

Behavioral Intention (BI) is a level that illustrates the intention of someone to use a technology (Deningtyas \& Ariyanti, 2017). BI is influenced by PE, EE, SI, FC, HM, PV, and HB, determining the use of technology (Use Behavior) (Venkatesh, Thong, \& Xu, 2012). When BI has a positive and significant value, then the possibility of actual use (use behavior) is even greater.

\section{H8: Behavioral intention has a strong and positive influence on us behavior}




\section{Research Methodology:-}

This study uses a survey method via Google Form which is distributed via email, Whatsapp, posting links on websites, personal blogs, and social networks. The population of this sample is all mobile payment users in Indonesia, aged 18 to more than 55 years old. using convenience sampling.Sample non-probability sampling technique. Samples are divided into several age groups, namely younger age groups consisting of age groups 18-24 years old and 25-34 years old, as well as older groups, namely the age group 35-44 years old and 45-55 + years old.

The population of mobile payment users is calculated based on calculation of penetration data mobile phones reduced by users who have not been touched by FinTech. Percentage of cell phone penetration reaches $67 \%$ of the population or as many as 177.9 million users (We Are Social, 2018), and that $69 \%$ of cell phone users have not been touched by fintech (CNN Indonesia, 2018), then fintech users amounted to $31 \%$ or as many as $55,149.000$ users.

The researcher then uses the Slovin formula to determine the number of samples. This formula was first introduced by Slovin in 1960. The Slovin formula is a formula used when the population is very large. This formula allows researchers to get a small sample, but can represent the entire population. This formula calculates the minimum number of samples if the behavior of a population is not known with certainty (Hidayat, 2017). The formula is as follows: $\mathrm{n}=\mathrm{N} /\left(1+\left(\mathrm{N} \mathrm{x} \mathrm{e}^{2}\right)\right)$, where $\mathrm{n}$ is the number of samples, $\mathrm{N}$ is the number of populations, and e is a standard. This study will use a standard of $5 \%$ or a degree of trust of $95 \%$.

In order to get the population as follows:

$\mathrm{n}=55,149,000 /\left(1+\left(55.149,000 \times 0.05^{2}\right)\right)$

$\mathrm{n}=55,149,000 /(1+(137,872.5))$

$\mathrm{n}=55,149,000 / 137,873.5$

$\mathrm{n}=399.99$

Based on the formula above the number of $n=399.99$ is generated, so the researchers set the number of samples to be 400 .

This research is analyzed by using statistical Least Square (PLS) tests using SmartPLS software. This technique was chosen because this study contains enough relations between variables that are more complex. This technique allows researchers to separate relationships between multiple variables that are more complex because there are many indicators involved. This technique is also more robust or double balance multiple regression analysis (Geladi \& Kowalski, 1986), so that research results can be more consistent when implemented in other types of research. From this analysis, the researcher wants to look at any variables that affect the acceptance and use of mobile payments in Indonesia, as well as see the strengths of their influence in different groups of people.

\section{Analysis and Results:-}

This research resulted in 400 respondents in the survey, with $15.3 \%$ respondents aged 18-24 years, $42.5 \%$ aged 25 34 years, $19.8 \%$ aged $35-44$ years, $10.3 \%$ aged $45-54$ years, and $12.3 \%$ aged more than 55 years. If there is a group in the youth and age groups, then the human group has a percentage of $60 \%$ and one group of $40 \%$. These results are sufficiently balanced to obtain representative results between human groups who act as moderating variables in this study.

\section{Usage Behavior}

The results of the study to answer the dependent variable Usage Behavior can be seen from the frequency of use, in which the researcher divides the answers into five groups, ie always (every day), often (3-4 times a week), sometimes (1-2 times a week), rarely (3-4 times a month), and rarely once. (1-2 times a month).

The results showed that $35.8 \%$ of respondents used mobile payment $3-4$ times a week, $25.5 \% 1-2$ times a week, and $23.8 \%$ used it every day. While $7 \%$ use it rarely or only 1-2 times in a period of months.

This shows that the respondent is an active mobile payment user, seen from the frequency of its use which is quite frequent in their daily activities. 


\section{Reliability and Validity Testing}

Before carrying out further analysis of the structural model, measurement analysis was carried out to test the validity and reliability of the study. This test was conducted using smartPLS software.

To test it, researchers conducted PLS Path Modeling calculations to see the value of Average Variance Extracted (AVE). From the first calculation, six indicators were found that have AVE values below 0.5, namely BI3, FC1, FC3, FC5, FC7, and SI3. After that, a second calculation is performed and all constructs have a AVE value of more than 0.5 and a Composite Reliability value of more than 0.7, which means that it is stated to be valid and reliable.

Construct Reliability and Validity

\begin{tabular}{|l|r|r|r|r|}
\hline & Cronbach's Alpha & \multicolumn{1}{|l}{ rho_A } & Composite Reliability & Average Variance Extracted (AVE) \\
\hline AGE & 1,000 & 1,000 & 1,000 & 1,000 \\
\hline BI & 0,902 & 0,922 & 0,924 & 0,640 \\
\hline EE & 0,942 & 0,944 & 0,958 & 0,852 \\
\hline FC & 0,684 & 0,699 & 0,824 & 0,610 \\
\hline HB & 0,877 & 0,881 & 0,924 & 0,802 \\
\hline HM & 0,695 & 0,694 & 0,831 & 0,622 \\
\hline Moderating Effect 1 & 1,000 & 1,000 & 1,000 & 1,000 \\
\hline Moderating Effect 2 & 1,000 & 1,000 & 1,000 & 1,000 \\
\hline Moderating Effect 3 & 1,000 & 1,000 & 1,000 & 1,000 \\
\hline Moderating Effect 4 & 1,000 & 1,000 & 1,000 & 1,000 \\
\hline Moderating Effect 5 & 1,000 & 1,000 & 1,000 & \\
\hline Moderating Effect 6 & 1,000 & 1,000 & 1,000 & \\
\hline Moderating Effect 7 & 1,000 & 1,000 & 1,000 & \\
\hline PE & 0,891 & 0,891 & 0,932 & \\
\hline PV & 0,931 & 0,938 & 0,951 & 1,000 \\
\hline SI & 0,750 & 0,858 & 0,838 & 1,000 \\
\hline USE & 1,000 & 1,000 & 1,000 & 1,000 \\
\hline
\end{tabular}

In addition, the researcher also looked at the Discriminant Validity, and found that all diagonal figures in the tabs were more thick than the numbers below, which indicated that all variables were valid and further analysis of the Structural Model could be carried out.

Discriminant Validity

\begin{tabular}{|c|c|c|c|c|c|c|c|c|c|c|c|c|c|c|c|c|c|}
\hline & AGE & BI & EE & FC & HB & HM & ME1 & ME2 & ME3 & ME4 & ME5 & ME6 & ME7 & PE & PV & si & USE \\
\hline AGE & 1,000 & & & & & & & & & & & & & & & & \\
\hline BI & $-0,106$ & 0,800 & & & & & & & & & & & & & & & \\
\hline EE & $-0,276$ & 0,576 & 0,923 & & & & & & & & & & & & & & \\
\hline FC & $-0,091$ & 0,690 & 0,557 & 0,781 & & & & & & & & & & & & & \\
\hline HB & $-0,044$ & 0,677 & 0,543 & 0,581 & 0,896 & & & & & & & & & & & & \\
\hline HM & $-0,188$ & 0,608 & 0,414 & 0,505 & 0,417 & 0,789 & & & & & & & & & & & \\
\hline Moderating Effect 1 & $-0,075$ & 0,128 & 0,329 & 0,096 & 0,134 & $-0,042$ & 1,000 & & & & & & & & & & \\
\hline Moderating Effect 2 & $-0,097$ & 0,168 & 0,308 & 0,180 & 0,194 & 0,015 & 0,776 & 1,000 & & & & & & & & & \\
\hline Moderating Effect 3 & 0,060 & $-0,009$ & 0,050 & $-0,022$ & $-0,001$ & $-0,086$ & 0,214 & 0,162 & 1,000 & & & & & & & & \\
\hline Moderating Effect 4 & $-0,033$ & 0,054 & 0,184 & 0,004 & 0,051 & $-0,052$ & 0,574 & 0,589 & 0,348 & 1,000 & & & & & & & \\
\hline Moderating Effect 5 & $-0,069$ & $-0,050$ & 0,015 & $-0,053$ & 0,092 & $-0,012$ & 0,353 & 0,368 & 0,359 & 0,480 & 1,000 & & & & & & \\
\hline Moderating Effect 6 & $-0,102$ & 0,072 & 0,152 & 0,071 & 0,096 & 0,073 & 0,403 & 0,421 & 0,244 & 0,537 & 0,643 & 1,000 & & & & & \\
\hline Moderating Effect 7 & $-0,016$ & 0,048 & 0,198 & 0,051 & $-0,023$ & 0,090 & 0,550 & 0,594 & 0,288 & 0,600 & 0,452 & 0,481 & 1,000 & & & & \\
\hline PE & $-0,215$ & 0,640 & 0,749 & 0,572 & 0,521 & 0,410 & 0,273 & 0,332 & 0,022 & 0,099 & $-0,044$ & 0,047 & 0,139 & 0,906 & & & \\
\hline PV & $-0,278$ & 0,563 & 0,444 & 0,526 & 0,448 & 0,645 & 0,045 & 0,146 & 0,015 & 0,070 & 0,073 & 0,115 & 0,095 & 0,449 & 0,910 & & \\
\hline SI & 0,162 & 0,351 & 0,096 & 0,327 & 0,269 & 0,339 & 0,021 & 0,048 & $-0,128$ & $-0,021$ & $-0,084$ & 0,015 & $-0,001$ & 0,169 & 0,180 & 0,802 & \\
\hline USE & $-0,313$ & 0,418 & 0,431 & 0,298 & 0,271 & 0,273 & 0,200 & 0,212 & $-0,007$ & 0,104 & 0,002 & 0,116 & 0,158 & 0,522 & 0,330 & 0,022 & 1,000 \\
\hline
\end{tabular}

\section{Hypothesis Testing}

Structural Model Analysis is conducted to test the research hypothesis. Both use the Bootstrapping method by multiplying the sample into 5000 sub-samples.

Testing is done by separating between groups of young people and old people, to see the significance and strength of the influence of variables in different groups of people.

In the results of the calculation of young people, where then it was found, that there were three variables that significantly affected the Behavior Intention to Use, namely Facilitating Condition, Habit, and Performance 
Expectancy, and Behavior Intention which also influenced the Usage Behavior. While the Effort Expectancy (pvalue 0,372), Hedonic Motivation (p-value) -value 0.239), Price Value (p-value 0.200), and Social Influence (pvalue 0.460 ) do not have a significant effect.

Mean, STDEV, T-Values, P-Values

\begin{tabular}{|l|r|r|r|r|r|}
\hline & Original Sample (O) & Sample Mean (M) & Standard Deviation (STDEV) & T Statistics (|O/STDEV|) & P Values \\
\hline BI $>$ UB & 0,485 & 0,492 & 0,127 & 3,821 & $\mathbf{0 , 0 0 0}$ \\
\hline EE $>$ BI & $-0,119$ & $-0,095$ & 0,133 & 0,893 & $\mathbf{0 , 3 7 2}$ \\
\hline FC $>$ BI & 0,272 & 0,263 & 0,107 & 2,546 & $\mathbf{0 , 0 1 1}$ \\
\hline FC $>$ UB & $-0,097$ & $-0,098$ & 0,103 & 0,941 & $\mathbf{0 , 3 4 7}$ \\
\hline HB $>$ BI & 0,263 & 0,241 & 0,131 & 2,016 & $\mathbf{0 , 0 4 4}$ \\
\hline HB $>$ UB & 0,145 & 0,143 & 0,135 & 1,071 & $\mathbf{0 , 2 8 4}$ \\
\hline HM > BI & 0,101 & 0,095 & 0,085 & 1,178 & $\mathbf{0 , 2 3 9}$ \\
\hline PE $>$ BI & 0,384 & 0,383 & 0,093 & 4,130 & $\mathbf{0 , 0 0 0}$ \\
\hline PV $>$ BI & 0,121 & 0,129 & 0,094 & 1,282 & $\mathbf{0 , 2 0 0}$ \\
\hline SI $>$ BI & 0,042 & 0,048 & 0,057 & 0,739 & $\mathbf{0 , 4 6 0}$ \\
\hline
\end{tabular}

Then when looking at the Path Coefficient value, it can be seen that the variable that chooses the strongest influence on Behavior Intention to Use in young people is Performance Expectancy (0.384), Facilitating Condition (0.272), and Habit (0.263). While other variables that have a positive Path Coefficient are Price Value (0.121), Hedonic Motivation (0.101), and Social Influence (0.042).

On the other hand, Behavior Intention has a Path Coefficient of 0.485 and Habit which also has a positive Path Coefficient of Usage Behavior with a value of 0.145 .

\section{Path Coefficients}

\begin{tabular}{|l|r|r}
\hline & BI & UB \\
\hline BI & & 0,485 \\
\hline EE & $-0,119$ & \\
\hline FC & 0,272 & $-0,097$ \\
\hline HB & 0,263 & 0,145 \\
\hline HM & 0,101 & \\
\hline PE & 0,384 & \\
\hline PV & 0,121 & \\
\hline SI & 0,042 & \\
\hline UB & & \\
\hline
\end{tabular}

Similar results also appear in calculations in the elderly group, where only Facilitating Condition, Habit, and Performance Expectancy have a significant influence on Behavior Intention to Use, which continues on Usage Behavior. While Effort Expectancy, Hedonic Motivation, Price Value and Social Influence do not have a significant influence with p-value more than 0.05 and T Statistics more than 1.96.

Mean, STDEV, T-Values, P-Values

\begin{tabular}{|l|r|r|r|r|r|}
\hline & Original Sample (O) & Sample Mean (M) & Standard Deviation (STDEV) & T Statistics (|O/STDEV|) & P Values \\
\hline BI $\rightarrow$ USE & 0,519 & 0,521 & 0,059 & 8,814 & 0,000 \\
\hline EE > BI & $-0,118$ & $-0,097$ & 0,136 & 0,870 & 0,384 \\
\hline FC $>$ BI & 0,266 & 0,256 & 0,108 & 2,471 & 0,014 \\
\hline HB $>$ BI & 0,265 & 0,249 & 0,132 & 2,001 & 0,045 \\
\hline HM $>$ BI & 0,100 & 0,096 & 0,084 & 1,189 & 0,235 \\
\hline PE $>$ BI & 0,386 & 0,384 & 0,093 & 4,162 & 0,000 \\
\hline PV > BI & 0,123 & 0,129 & 0,094 & 1,320 & 0,187 \\
\hline SI $>$ BI & 0,042 & 0,048 & 0,057 & 0,745 & 0,456 \\
\hline
\end{tabular}

When looking at the Path Coefficient calculations, it can be seen that the variable that has the most powerful influence on Behavior Intention for the elderly group is Performance Expectancy (0.386), Facilitating Condition (0.266), and Habit (0.265). While other variables that have positive path coefficient coefficient are Price Value (0.123), Hedonic Motivation (0.100), and Social Influence (0.042). 


\section{Path Coefficients}

\begin{tabular}{|l|r|r}
\hline & BI & USE \\
\hline BI & & 0,519 \\
\hline EE & $-0,118$ & \\
\hline FC & 0,266 & \\
\hline HB & 0,265 & \\
\hline HM & 0,100 & \\
\hline PE & 0,386 & \\
\hline PV & 0,123 & \\
\hline SI & 0,042 & \\
\hline USE & & \\
\hline
\end{tabular}

If it is compared, then we can also see that the Path Coefficient value for the group of people is one or even different, and 6) Social Influence, which is the same as the Impact.

While eight hypotheses were proposed, only four were accepted, namely H5, H6, H7a, and H8, in which Hedonic Motivation affected Behavior Intention to Use and its influence was stronger in the older human group (H5), Price Value influenced Behavior Intention to Use and its influence was stronger in the older group (H5). (H6), and Habit influences Behavior Intention to Use and its influence is stronger in the older group of people (H7a), and Behavior Intention which influences Usage Behavior (H8).

\begin{tabular}{|c|c|c|c|c|c|c|c|}
\hline \multirow{2}{*}{ Variables } & \multicolumn{3}{|c|}{ Path Coefficient BI } & \multicolumn{3}{|c|}{ Path Coefficient UB } & \multirow{2}{*}{$\begin{array}{l}\text { Hypothesis } \\
\text { Supported? }\end{array}$} \\
\hline & Gabung & Muda & Tua & Gabung & Muda & Tua & \\
\hline Age & 0,016 & & & & & & No \\
\hline BI & & & & 0,419 & 0,485 & 0,519 & No \\
\hline EE & $-0,034$ & $-0,119$ & $-0,118$ & & & & No \\
\hline FC & 0,223 & 0,272 & 0,266 & 0,024 & $-0,097$ & & No \\
\hline HB & 0,305 & 0,263 & 0,265 & $-0,027$ & 0,145 & & Yes \\
\hline HM & 0,226 & 0,101 & 0,1 & & & & Yes \\
\hline ME1 & 0,06 & & & & & & No \\
\hline ME2 & $-0,074$ & & & & & & No \\
\hline ME3 & 0,028 & & & & & & No \\
\hline ME4 & 0,071 & & & & & & No \\
\hline ME5 & $-0,103$ & & & & & & No \\
\hline ME6 & 0,035 & & & & & & No \\
\hline ME7 & $-0,02$ & & & & & & No \\
\hline PE & 0,245 & 0,384 & 0,386 & & & & No \\
\hline PV & 0,07 & 0,121 & 0,123 & & & & Yes \\
\hline SI & 0,065 & 0,042 & 0,042 & & & & No \\
\hline
\end{tabular}

No effect on Effort Expectancy or increased ease of use of a technology has been caused because the technology is developing with very fast in the last year. The use of technology in an older group of people who were previously thought to be less tech-savvy has actually been more easy to adapt to the development of the times. This also makes the difference between not being a body and a factor that influences the acceptance of a person against new technology (in this case mobile payment), which results in the use of the mobile payment itself.

This result is also supported by the fact that the level of strength of each variable has less than the same value among groups of people, showing that there are no other variables that affect the acceptance and use of a very new technology.

While, if, this is more in the past, we have seen that the Facilitating Condition which is a supporting infrastructure that increases the user intention to use mobile payment is actually stronger in the human group than in the elderly, because consumers are more likely to be chosen. In this sense, when the camera is in a way that a provider does not have a good infrastructure, then it is easy to move to another provider that can provide better infrastructure. Another 
thing is with the older group of people who are more likely to look for safety by using applications that they have already known before.

This is also supported by results that show that Performance Expectancy has a stronger influence on older groups, because they have a tendency to use more familiar applications, so that the performance of it, is an important factor. When the application cannot be used, then it is assumed that they will find more meaningful obstacles for young people who are more easily moved to other applications.

Finally, social influence or the influence of the environment around the user in determining the Behavior Intention to Use appears to have a very small coefficient in both groups of people, which means that the effect is very small. This could have been due to the fact that users of this period have been able to increase their own needs, so that they would not be influenced by others to use a new technology.

\section{Conclusions And Suggestions:-}

From the results of calculations using the MSSPL above, it can be concluded that humanity does not have the influence on the acceptance and use of mobile payment in Indonesia.

The results of the calculation of the influence on the two groups of people also showed that they were not different, where Performance Expectancy, Facilitating Condition, and Habits were the same variables that gave a significant influence on both groups of people.

This shows that the company as a provider of mobile payment services must maintain its application, increase network and improve its infrastructure, as well as provide a promotion that makes people become used using mobile payment applications in day-to-day activities, which then, it leads to "dependency" on users of these mobile payment services.

Companies are also advised to continue to maintain the ease of use of the application as well as the promos provided, although the Variable Effort Expectancy and Price Value do not show a significant effect. This is because the two variables are judged to be correlated with both Performance Expectancy and Hedonic Motivation, which are variables that have a significant effect.

However, seeing that the value of Social Influence is so small and has no effect, the company is advised for not to influence too much on focus or promotion budget for the programs that involve people, such as influencer marketing, brand ambassadorship, member-get-member programs, referral programs, or other related similar programs. Researchers suggest that companies focus the budget of these programs so that they are able to be diverted to other variables that, indeed, show a significant influence on the acceptance and use of mobile payment, so the application of increases and the performance of the business can continue to grow.

This research is limited to residents in the large cities that tend to be more digital savvy. For this reason, the next research could be suggested to conduct in rural areas, or, even to conduct one of a similar type that is correlated with other types of financial technology.

\section{Reference:-}

1. Agusta, J. (2018). Mobile Payments in Indonesia: A Race to Big Data Domination (MDI Ventures Industry Report). Retrieved from. MDI Ventures website.

2. Berpotensi, 69 Persen Pengguna Ponsel Belum Terjamah Fintech. (2018). Retrieved from https://www.cnnindonesia.com/teknologi/20180731193952-185-318472/berpotensi-69-persen-penggunaponsel-belum-terjamah-fintech

3. Cabanillas, F. L., Fernández, J. S., \& Leiva, F. M. (2015). Influence of age in the adoption of new mobile payment systems. Rev. bus. manag, 17(58), 1390-1407. doi:10.7819/rbgn.v17i58.1989.

4. Fintech Indonesia. (2018). Retrieved from https://www.cekindo.com/fintech-indonesia.html

5. Chang, A. (2012). UTAUT AND UTAUT 2: A REVIEW AND AGENDA FOR FUTURE RESEARCH. Journal The WINNERS, 13(2), 106-114.

6. Daştan, I., \& Gürler, C. (2016). Factors Affecting the Adoption of Mobile Payment Systems: An Empirical Analysis. Emerging Markets Journal, 6(1), 9. doi: 2158-8708. 
7. Deningtyas, F., \& Ariyanti, M. (2017, May 4-5). Factors Affecting The Adoption of E-Payment on Transportation Service Application Using Modified Unified Technology of Acceptance and Use of Technology 2 Model. International Journal of Management and Applied Science (IJMAS), 3(7), 73-78.

8. Dennehy, D., \& Sammon, D. (2015). Trends in mobile payments research: A literature review. Journal of Innovation Management, 3, 49-61. ISSN 2183-0606.

9. Fintech in Indonesia. (2018). Retrieved from https://www.statista.com/outlook/295/120/fintech/indonesia

10. Franedya, R. (2018, January 12). Mulai Dari Milenial Hingga UKM Bisa Akses Fintech. Retrieved from https://www.cnbcindonesia.com/fintech/20180112144801-37-1340/mulai-dari-milenial-hingga-umkm-bisaakses-fintech

11. Gartner IT Glossary Mobile Payment. (2018). Retrieved from https://www.gartner.com/it-glossary/mobilepayment

12. Hidayat, A. (2017, December 16). Cara Hitung Rumus Slovin. Retrieved from https://www.statistikian.com/2017/12/hitung-rumus-slovin-sampel.html

13. Isa, S. M., \& Wong, K.-Y. (2015). Age Differences in Behavioral Intention to Use Internet Marketing: A Comparative Study Between Malaysian and Taiwanese. International Journal of Business and Society, 16(3), 386-396.

14. Kim, Y., Park, Y.-J., Choi, J., \& Yeon, J. (2016). The Adoption of Mobile Payment Services for "Fintech". International Journal of Applied Engineering Research, 11(2), 1058-1061. ISSN 0973-4562.

15. Kotler, P., Keller, Kevin L. (2016). Marketing Management. Analyzing Consumer Markets (pp. 179-209). Essex, England: Pearson.

16. Levine, David M., Stephan, David F., Szabat, Kathryn A. (2017). Ebook Statistics for Managers 8th Edition. Introduction to Multiple Regression (pp. 499-528). Essex, England: Pearson.

17. Manaf, N. R., \& Ariyanti, M. (2017, January). Exploring Key Factors on Technology Acceptance of Mobile Payment Users in Indonesia Using Modified Unified Theory of Acceptance and Use of Technology (UTAUT) Model Use Case: ABC Easy Tap. International Journal of Management and Applied Science, 3(1), 5. ISSN 2394-7926.

18. Riskinanto, A., Kelana, B., \& Hilmawan, D. R. (2017). The Moderation Effect of Age on Adopting E-Payment Technology. Procedia Computer Science, 124, 536-543.

19. Schueffel, P. (2016). Taming the Beast: A Scientific Definition of Fintech. Journal of Innovation Management, 4(4), 32-54. ISSN 2183-0606.

20. Varga, D. (2017, November 3). Fintech, The New Era of Financial Services. Budapest Management Review, XLVIII, 11. ISSN 0133-0179.

21. Venkatesh, V., Thong, J. Y., \& Xu, X. (2012). CONSUMER ACCEPTANCE AND USE OF INFORMATION TECHNOLOGY: EXTENDING THE UNIFIED THEORY OF ACCEPTANCE AND USE OF TECHNOLOGY. MIS Quarterly, 36(1), 157-178.

22. We Are Social. (2018). Digital in 2018 in Southeast Asia Part 2. Retrieved from We Are Social: https://www.slideshare.net/wearesocial/digital-in-2018-in-southeast-asia-part-2-southeast-86866464

\section{Appendix}

\section{Operationalization of Constructs}

The operationalization of the variables that will be used as a basis for making this questionnaire based on survey questions conducted by Venkatesh on mobile internet in 2012, which then modified the whole according to the needs of this research, namely in the context of the use of mobile payment.

\begin{tabular}{|l|l|l|}
\hline Variable & Operational definition & Measures \\
\hline Age & $\begin{array}{l}\text { Age Calculate by Year of birth of } \\
\text { the study population. Starting } \\
\text { from 1950 to 2000. }\end{array}$ & $\begin{array}{l}\text { Age of Respondents Divided by 5 age groups, } \\
\text { namely 18--24 years, 25-34 years, 35-44 years, } \\
\text { 45-55 years old, and more than 55 years old. }\end{array}$ \\
\hline Use behavior (UB) & $\begin{array}{l}\text { Describe Frequency of Use which } \\
\text { shows usage behavior towards } \\
\text { mobile payment, as well as the } \\
\text { usage purpose of the mobile } \\
\text { payment. UB is influenced by all } \\
\text { the variables above. }\end{array}$ & (UB1) I use mobile payment (frequency of use) \\
\hline $\begin{array}{l}\text { Performance Expectancy } \\
\text { (PE) }\end{array}$ & $\begin{array}{l}\text { The rate at which someone trusts } \\
\text { that using mobile payment makes } \\
\text { him/her get more benefits. The }\end{array}$ & $\begin{array}{l}\text { (PE1) Using mobile payment helps everyday } \\
\text { activities }\end{array}$ \\
\cline { 3 - 4 } & &
\end{tabular}




\begin{tabular}{|c|c|c|}
\hline & \multirow{2}{*}{$\begin{array}{l}\text { benefits or advantages that are } \\
\text { gained and making him/her be } \\
\text { more likely to receive and use } \\
\text { mobile payment. }\end{array}$} & transactions possible to be easier and faster \\
\hline & & $\begin{array}{l}\text { (PE3) Using mobile payment is increasing my } \\
\text { productivity }\end{array}$ \\
\hline \multirow[t]{4}{*}{ Effort Expectancy (EE) } & \multirow{4}{*}{$\begin{array}{l}\text { The level of ease of use of mobile } \\
\text { payment. If Someone Feels Using } \\
\text { mobile payment is easy (small } \\
\text { effort), then he/she will tend to } \\
\text { accept and use mobile payment. }\end{array}$} & $\begin{array}{l}\text { (EE1) Learning on how to use mobile payment } \\
\text { is very easy for me }\end{array}$ \\
\hline & & $\begin{array}{l}\text { (EE2) I easily understand how to use mobile } \\
\text { payment }\end{array}$ \\
\hline & & $\begin{array}{l}\text { (EE3) The menu or features in mobile payment } \\
\text { are easy to understand }\end{array}$ \\
\hline & & $\begin{array}{l}\text { (EE4) It's easy to navigate pages or menus on } \\
\text { mobile payments }\end{array}$ \\
\hline \multirow[t]{3}{*}{ Social Influence (SI) } & \multirow{3}{*}{$\begin{array}{l}\text { The rate at which people around } \\
\text { users use mobile payments, so } \\
\text { users need to use mobile } \\
\text { payments (the effect of } \\
\text { environmental use). }\end{array}$} & $\begin{array}{l}\text { (SI1) I use mobile payment because friends / } \\
\text { family / spouses who are important to me are } \\
\text { also using it }\end{array}$ \\
\hline & & $\begin{array}{l}\text { (SI2) I use mobile payment because people who } \\
\text { influence my behavior recommend me to use it }\end{array}$ \\
\hline & & $\begin{array}{l}\text { (SI3) I use mobile payment because celebrities / } \\
\text { public figures also use it }\end{array}$ \\
\hline \multirow[t]{7}{*}{ Facilitating Condition (FC) } & \multirow{7}{*}{$\begin{array}{l}\text { Describe the supporting } \\
\text { infrastructure that increases user } \\
\text { intention to use mobile payment. } \\
\text { The more and more complete } \\
\text { infrastructure available, the } \\
\text { greater the possibility for people } \\
\text { to accept and use mobile } \\
\text { payment. }\end{array}$} & $\begin{array}{l}\text { (FC1) I use a mobile payment because it's } \\
\text { compatible with my mobile }\end{array}$ \\
\hline & & $\begin{array}{l}\text { (FC2) I use mobile payment because there are } \\
\text { many merchants available }\end{array}$ \\
\hline & & $\begin{array}{l}\text { (FC3) I use mobile payment because its } \\
\text { application can be used in many cities / } \\
\text { countries }\end{array}$ \\
\hline & & $\begin{array}{l}\text { (FC4) I use a mobile payment because the } \\
\text { company's supply is reliable and reliable }\end{array}$ \\
\hline & & $\begin{array}{l}\text { (FC5) I use mobile payments because there is } \\
\text { no transaction fee that is charged to the user }\end{array}$ \\
\hline & & $\begin{array}{l}\text { (FC6) I use mobile payment because I can find } \\
\text { information sharing to use mobile payment }\end{array}$ \\
\hline & & $\begin{array}{l}\text { (FC7) I use mobile payment because I can ask } \\
\text { others if I find it difficult to use it }\end{array}$ \\
\hline \multirow[t]{3}{*}{ Hedonic Motivation (HM) } & \multirow{3}{*}{$\begin{array}{l}\text { Describes the pleasure obtained } \\
\text { from using mobile payment. As } \\
\text { long as someone is happy in using } \\
\text { certain technologies, their use } \\
\text { will also increase. }\end{array}$} & $\begin{array}{l}\text { (HM1) I use mobile payment because it gives } \\
\text { me pleasure }\end{array}$ \\
\hline & & $\begin{array}{l}\text { (HM2) I use mobile payment because I can } \\
\text { collect points and it makes me happy }\end{array}$ \\
\hline & & $\begin{array}{l}\text { (HM3) I use mobile payment because I can get } \\
\text { a lot of promos and it makes me happy }\end{array}$ \\
\hline \multirow[t]{4}{*}{ Price Value (PV) } & \multirow{4}{*}{$\begin{array}{l}\text { Describe the value or value } \\
\text { between the benefits obtained, } \\
\text { compared with the costs that must } \\
\text { be spent to use mobile payment } \\
\text { (value for money). When users } \\
\text { feel the value obtained is greater } \\
\text { than the costs incurred, then the } \\
\text { intention to use mobile payment } \\
\text { is increasing. }\end{array}$} & $\begin{array}{l}\text { (PV1) I use mobile payment because many } \\
\text { promos are offered }\end{array}$ \\
\hline & & $\begin{array}{l}\text { (PV2) I use a mobile payment because many } \\
\text { discounts are given }\end{array}$ \\
\hline & & $\begin{array}{l}\text { (PV3) I use mobile payment because I get } \\
\text { cheaper prices }\end{array}$ \\
\hline & & $\begin{array}{l}\text { (PV4) I use mobile payment because it provides } \\
\text { value for money }\end{array}$ \\
\hline \multirow[t]{3}{*}{ Habit (HB) } & \multirow{3}{*}{$\begin{array}{l}\text { Describes frequently or user } \\
\text { habits in using new technology, } \\
\text { which makes users more likely to } \\
\text { accept and use mobile payments }\end{array}$} & $\begin{array}{l}\text { (HB1) I am used to taking new technology / } \\
\text { applications }\end{array}$ \\
\hline & & $\begin{array}{l}\text { (HB2) The technology of customization has } \\
\text { made my life easy }\end{array}$ \\
\hline & & $\begin{array}{l}\text { (HB3) I always update with the latest } \\
\text { technology }\end{array}$ \\
\hline
\end{tabular}




\begin{tabular}{|c|c|c|}
\hline \multirow[t]{7}{*}{ Behavioral Intention (BI) } & \multirow{7}{*}{$\begin{array}{l}\text { Describe someone's interest in } \\
\text { using mobile payment. BI is } \\
\text { influenced by PE, EE, SI, FC, } \\
\mathrm{HM}, \mathrm{PV} \text {, and HB. When BI is } \\
\text { positive and significant, then the } \\
\text { possibility of actual use (use } \\
\text { behavior) is even greater. }\end{array}$} & $\begin{array}{l}\text { (BI1) The benefits I get from mobile payments } \\
\text { (performance expectancy) make me want to use } \\
\text { mobile payments }\end{array}$ \\
\hline & & $\begin{array}{l}\text { (BI2) The ease of use of mobile payments } \\
\text { (effort expectancy) makes me want to use } \\
\text { mobile payments }\end{array}$ \\
\hline & & $\begin{array}{l}\text { (BI3) Increasingly friends / family / spouse / } \\
\text { public figures who use mobile payment (social } \\
\text { influence) make me want to use mobile } \\
\text { payment }\end{array}$ \\
\hline & & $\begin{array}{l}\text { (BI4) More and more infrastructure that accepts } \\
\text { mobile payment payments (facilitating } \\
\text { conditions) makes me want to use mobile } \\
\text { payments more }\end{array}$ \\
\hline & & $\begin{array}{l}\text { (BI5) The pleasure that can be obtained from } \\
\text { using mobile payment (hedonic motivation) } \\
\text { will make me more willing to use mobile } \\
\text { payment. }\end{array}$ \\
\hline & & $\begin{array}{l}\text { (BI6) When the value obtained is higher than } \\
\text { the cost incurred (price value) will make me } \\
\text { more willing to use mobile payment }\end{array}$ \\
\hline & & $\begin{array}{l}\text { (BI7) As long as you get used to the new } \\
\text { technology (habit) will make you want to use } \\
\text { mobile payment }\end{array}$ \\
\hline
\end{tabular}

